\title{
Ośrodek Tradycji Garncarstwa w Chałupkach (Góry Świętokrzyskie) jako obiekt geoturystyczny
}

\section{Pottery Tradition Centre at Chałupki (Holy Cross Mts) as a geoturistic object}

\author{
Anna Fijałkowska-Mader ${ }^{1 *}$, Grzegorz Pabian², Paweł Król $^{3}$ \\ ${ }^{1}$ Państwowy Instytut Geologiczny - Państwowy Instytut Badawczy, Oddziat Świętokrzyski, ul. Zgoda 21, 25-953 Kielce \\ ${ }^{2}$ Uniwersytet Jana Kochanowskiego w Kielcach, Instytut Geografii, Zakład Geoturystyki i Geologii Środowiskowej, \\ ul. Świętokrzyska 15, 25-406 Kielce \\ ${ }^{3}$ Muzeum Narodowe w Kielcach, Dziat Historii Naturalnej, plac Zamkowy 1, 25-010 Kielce \\ lanna.mader@pgi.gov.pl; ${ }^{2}$ g.pabian@wp.pl; ${ }^{3}$ p.krol@mnki.pl
}

\section{* Corresponding Author}
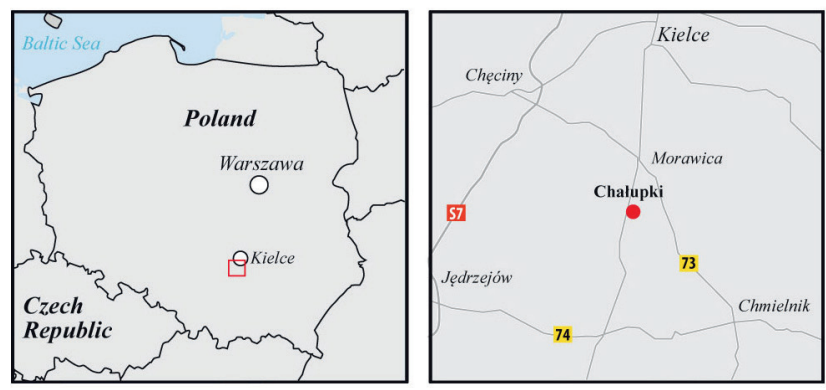

Article history:

Received: 18 October 2018

Accepted: 30 October 2019

Available online: 19 December 2019

(C) 2019 Authors. This is an open access publication, which can be used, distributed and reproduced in any medium according to the Creative Commons CC-BY 4.0 License requiring that the original work has been properly cited.

Treść: Z dużym prawdopodobieństwem można przyjąć, że wiejski ośrodek garncarski w rejonie dzisiejszej miejscowości Chatupki (gmina Morawica) należy do najstarszych $w$ regionie świętokrzyskim i funkcjonowat już w czasach rzymskich (II w n.e.). Okres jego świetności przypada na XVIII i XIX w. W dwudziestoleciu międzywojennym liczyt prawie 70 warsztatów i liczba ta stopniowo malała aż do roku 1993, kiedy został zamknięty ostatni warsztat Stefana Sowińskiego. Garncarstwo rozwinęło się z wykorzystaniem lokalnych złóz krasowych glin neogeńskich, występujących w obrębie lejów krasowych utworzonych w wapieniach górnej jury. Gliny te pozyskiwano szybikami na obszarze około 8,6 km², obejmujacym miejscowość Chatupki i ciagnacym się na poludnie od niej. Proces produkcji ceramiki byt wieloetapowy. Obejmowat przygotowanie gliny, tzw. ,,gojenie”, formowanie naczyń na toczku garncarskim, suszenie, glazurowane i wypalanie w piecach. Asortyment wyrobów ceramicznych ulegt z czasem wzbogaceniu. Obok naczyń użytkowych pojawiły się zabawki, głównie gwizdki, oraz kropielnice i figury świętych. Ceramika z Chałupek była używana nie tylko przez ludność lokalna, lecz w catym regionie świętokrzyskim, a nawet poza jego granicami. Z biegiem czasu zmieniało sie jej przeznaczenie od czysto użytkowego po dekoracyjne. Od 1998 r. funkcjonuje w Chatupkach Ośrodek Tradycji Garncarstwa, petniacy rolę muzealno-edukacyjna. Corocznie, w lipcu, na terenie ośrodka odbywa się festyn etnograficzny „Chałupkowe Garncynki”. Ośrodek Tradycji Garncarstwa w Chałupkach jest licznie odwiedzany przez turystów zarówno indywidualnych, jak i grupy zorganizowane oraz wycieczki szkolne. Stanowi obiekt geoturystyczny promujący dziedzictwo kulturowe Chatupek.

Słowa kluczowe: garncarstwo, Chałupki, obiekt geoturystyczny

\begin{abstract}
It is highly probable that the rural pottery center in the area of today's Chatupki (Morawica commune) is one of the oldest in the Świętokrzyskie region, as it was already functioning in Roman times (II in A.D.). The period of its glory falls during the eighteenth and nineteenth centuries. In the interwar period, it held almost 70 workshops, and this number gradually decreased until 1993, when the last workshop of Stefan Sowiński was closed. The basis for the establishment of pottery came from the local karstic Neogene clays, occurring within karst funnels developed in the Upper Jurassic limestones. The clays were obtained by shafts in the area of approx. $8.6 \mathrm{~km}^{2}$, covering the village of Chatupki and extending to the south of it. The production process of the ceramics was multi-stage. It included the preparation of clay, the so-called "healing", forming dishes on a potter's toast, drying, glazing and baking in ovens. The range of ceramic products has been enriched over time. Next to utility vessels, toys appeared, mainly whistles, as well as bowls and statuettes of saints. Earthenware from
\end{abstract}


Chatupki was used not only by the local population, but also in the entire Świętokrzyskie region, and even outside its borders. Over time, its role changed from purely useful to decorative. Since 1998, the Center of Pottery Tradition has been operating in Chatupki, which is both a museum and an educational object. Every year, in July, the center hosts the ethnographic festival "Chatupkowe Potions". The Pottery Tradition Center in Chatupki is frequented by tourists, both individual and organized groups, as well as school trips. It is a geotouristic object promoting the cultural heritage of Chatupki.

Key words: pottery, Chatupki, geotourist object

\section{Wstęp}

Miejscowość Chałupki położona jest w południowej części Gór Świętokrzyskich, w gminie Morawica, w odległości około $18 \mathrm{~km}$ na południe od Kielc, przy drodze prowadzącej z Morawicy do Kij (Fig. 1) i Pińczowa. Pod względem geomorfologicznym obszar ten stanowi wschodnie zakończenie Pasma Chęcińsko-Zbrzańskiego (Kondracki, 2002).

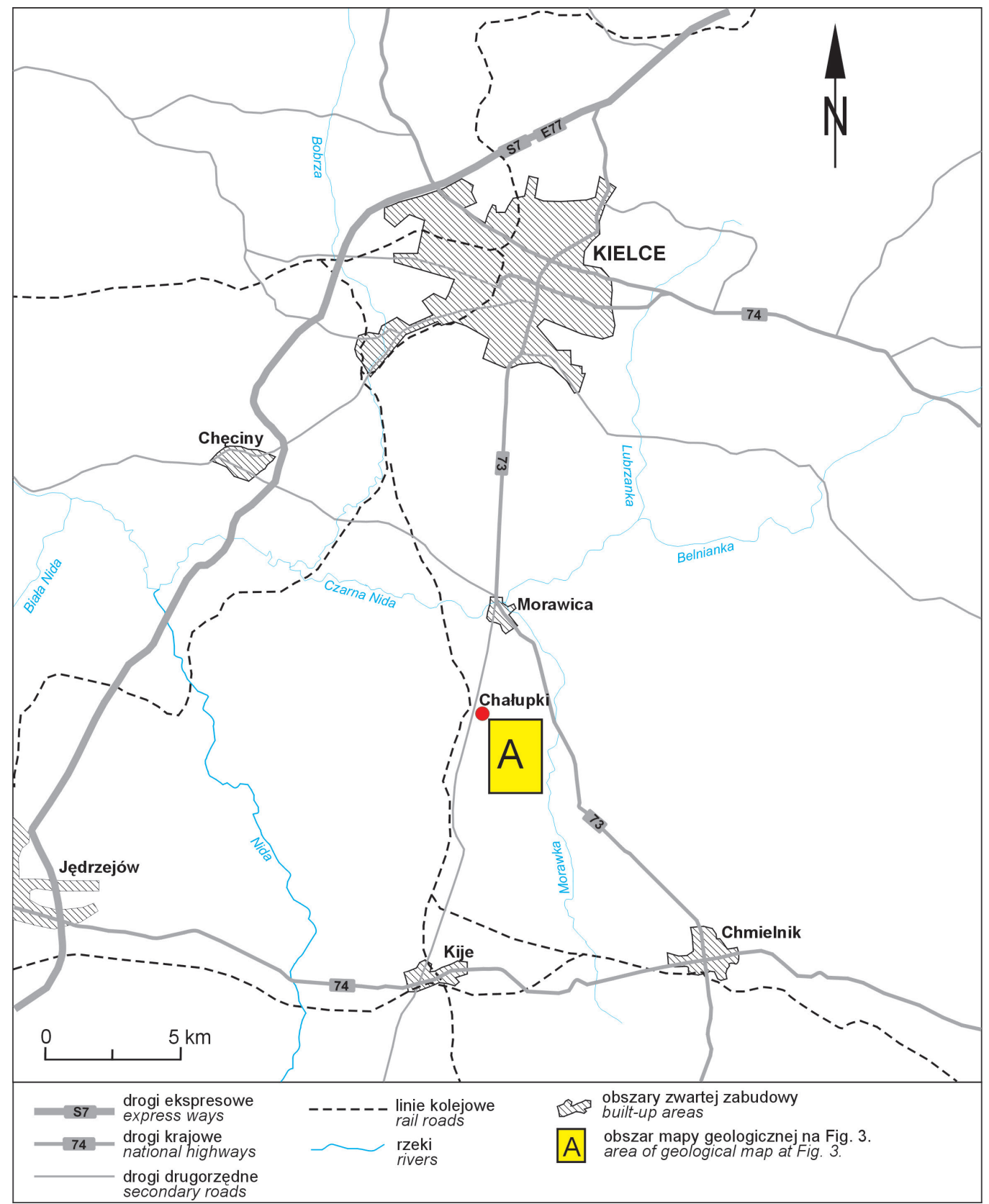

Fig. 1. Szkic lokalizacyjny miejscowości Chałupki • Location sketch of Chałupki 
Podczas prac archeologicznych w północno-zachodniej części wsi natrafiono na fragmenty naczyń datowane na II w n.e. (Fijałkowska \& Fijałkowski, 1984). Natomiast podczas kopania gliny natrafiono w pobliżu Chałupek na fragmenty ceramiki z XVI-XVII (Erber, 1984). Pierwsza wzmianka o garncarstwie w rejonie wsi Chałupki pochodzi z XVIII wieku i znajduje się w opisie podróży po Polsce niemieckiego geologa Filipa Carosiego (1781-1784). Od tego czasu ośrodek działał nieprzerwanie do lat 90. ubiegłego wieku. W okresie międzywojennym liczył nawet 69 warsztatów (Erber, 1984). Po drugiej wojnie światowej, kiedy spadło zapotrzebowanie na gospodarcze naczynia gliniane, produkowano tu głównie donice do kwiatów, ozdobne naczynka, figurki i galanterię ceramiczną.

W 1996 r., z inicjatywy mieszkańców Chałupek, Urzędu Gminy w Morawicy, Muzeum Narodowego w Kielcach oraz Wojewódzkiego Domu Kultury, zaczęto budowę muzeum Ośrodka Tradycji Garncarstwa, które otwarto 4 października 1998 r. Jest to obiekt muzealno-edukacyjny, całoroczny, składający się z części ekspozycyjnej, ukazującej dzieje garncarstwa w Chałupkach, oraz z części warsztatowej, gdzie prowadzone są zajęcia edukacyjne przez miejscowego garncarza.

\section{Lokalna baza surowcowa służąca do rozwoju garncarstwa}

Rozwój garncarstwa w rejonie Chałupek nie byłby możliwy bez lokalnej bazy surowcowej, czyli glin i iłów dających się wypalać. Występowanie różnych typów glin garncarskich na omawianym terenie ma ścisły związek z jego budową geologiczną.

Obszar Chałupek należy do dwóch jednostek tektonicznych wchodzących w skład południowo-zachodniego obrzeżenia permsko-mezozoicznego Gór Świętokrzyskich wschodniego krańca antykliny Zbrzy, zbudowanego z utworów triasu (pstrego piaskowca, retu, wapienia muszlowego i kajpru), oraz zachodniej części synkliny Piotrkowic, utworzonej z wapieni górnej jury. Obraz tektoniczny komplikują liczne uskoki o charakterze zrzutowym i zrzutowo-przesuwczym. Powodują one, że skały triasowe kontaktują bezpośrednio (strefę kontaktu zakrywają utwory czwartorzędowe) z wapieniami górnojurajskimi oksfordu (Czarnocki, 1927; Stupnicka, 1972) (Fig. 2; Fig. 3).

Pod koniec kredy i w paleogenie górnojurajskie skały węglanowe permsko-mezozoicznego obrzeżenia ulegały intensywnemu krasowieniu (Drzał, 1966; Kosmowska-Suffczyńska, 1966; Majchert, 1966; Walczowski, 1966; Urban (red.), 1996; Złonkiewicz \& Kasza, 2016). Leje i zagłębienia zostały wypełnione pstrymi glinami rezydualnymi, stanowiącymi surowiec dla garncarzy. Oznaczenie wieku tych glin jest problematyczne z powodu braku w nich jakichkolwiek skamieniałości (Fijałkowska, 1988). Poprzez analogię do podobnych osadów, występujących w kotłach krasowych okolic Ostrowca Świętokrzyskiego, których wiek został określony jako mioceński (Samsonowicz, 1923), Czarnocki (1927) przyjął ten sam wiek dla glin rejonu Chałupek.

W rejonie Chałupek wychodnie utworów neogeńskich, o łącznej powierzchni czterech kilometrów kwadratowych, koncentrują się (Fig. 3) na południe od zabudowań Kolonii Chałupki, w Dębinie i na wschodnim skłonie góry Pasieczyska (Fijałkowska \& Fijałkowski, 1984). Profil glin w rejonie Chałupek ma na ogół od kilku do kilkunastu metrów miąższości i zawiera zróżnicowane osady. Idąc od spągu, można wymienić je następująco: krasowe gliny rezydualne barwy ochrowej, zawierające limonit (Fig. 4E), otoczaki wapieni i okruchy krzemieni górnojurajskich, reprezentujące dolną część kompleksu glin pstrych w schemacie litostratygraficznym tzw. trzeciorzędu lądowego, przedstawionym przez Fijałkowską \& Fijałkowskiego (1966). Wyżej leżą gliny pstre o przewadze barwy żółtej z soczewkami i gniazdami gliny wiśniowej, fioletowej, seledynowej lub białej, przechodzącymi obocznie w pstre, głównie czerwone, mułki kwarcowe (środkowa część kompleksu glin pstrych; Fig. 4D). Określenie genezy glin pstrych wymaga dalszych badań, gdyż nie można wykluczyć ich częściowo eluwialnego charakteru (por. Ludwikowska-Kędzia, 2018). Na glinach pstrych spoczywają gliny i iły szare z soczewkami ciemnoszarych iłów, lokalnie zawierających lignit (górna część kompleksu glin pstrych; Fig. 4C).

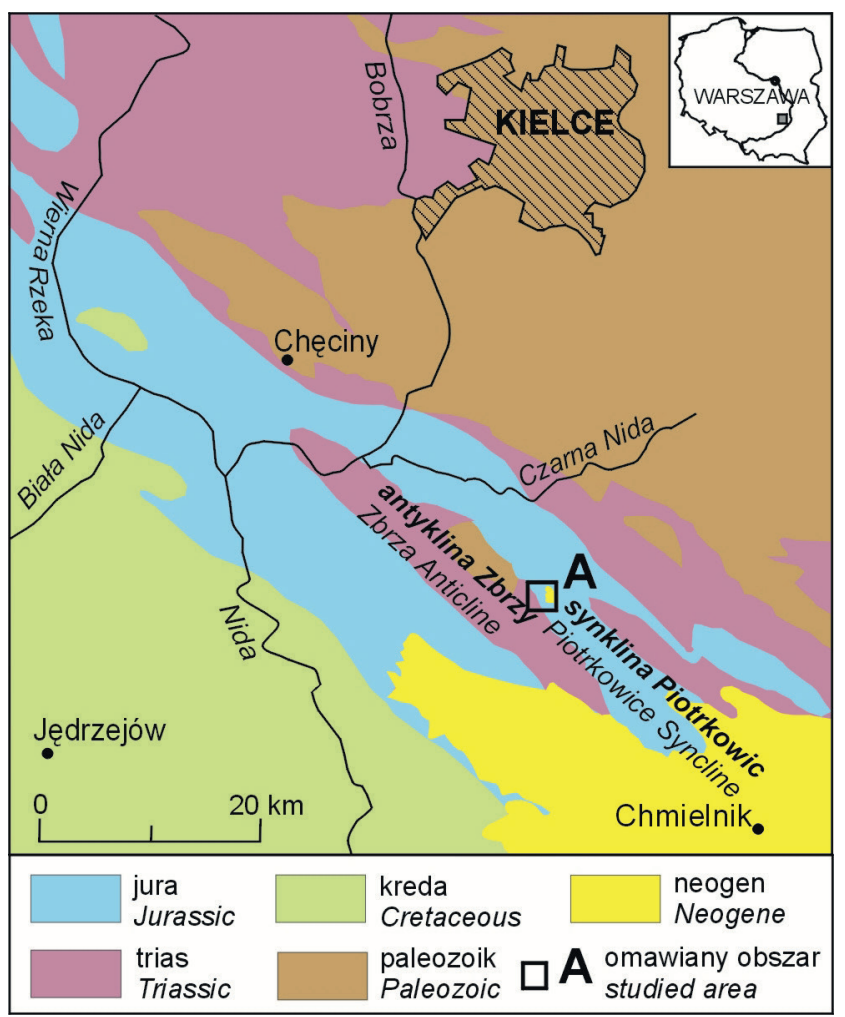

Fig. 2. Lokalizacja obszaru badań na tle uogólnionej mapy geologicznej Gór Świętokrzyskich 1:200 000 (wg Wróblewscy, 1996) - Location of studied area against generalized geologic map of the Holy Cross Mountains 1:200 000 (after Wróblewscy, 1996) 
Obecność lignitu i pozioma laminacja iłów może wskazywać na jeziorno-bagnistą genezę w lokalnym zbiorniku, który utworzył się w obniżeniu nad zaczopowanym lejem krasowym. Profil miocenu kończą ceglaste, miejscami seledynowe mułki kwarcowe (Fig. 4B), przykryte luźnymi utworami plioceńskimi (?), szarymi piaskami kwarcowymi zawierającymi górnojurajskie krzemienie (Fig. 4A), szarymi iłami, mułkami i mułowcami. Reprezentują one osady deluwialne i aluwialne, związane z okresowymi spływami wód i być może sedymentacją eoliczną (Czarnocki, 1927; Filonowicz, 1968; Fijałkowska \& Fijałkowski, 1965).

W związku ze swą genezą złoże glin pstrych ma bardzo nieregularny charakter. Miąższość poszczególnych litosomów w obrębie kompleksu zmienia się na stosunkowo niewielkim obszarze, a miejscami one zupełnie zanikają.

Gliny ochrowe i pstre, $z$ dolnego i środkowego kompleksu glin pstrych, stanowiły główny surowiec do wyrobu ceramiki. Skład uziarnienia i skład chemiczny wybranych próbek został przedstawiony w pracy Fijałkowska \& Fijałkowski (1984). W stosunku do neogeńskich glin garncarskich z rejonu Małogoszcza, Łagowa czy Ostrowca Świętokrzyskiego surowiec z Chałupek zawiera więcej węglanu wapnia (do $3 \%$ wagowych) i tlenku żelaza (nawet powyżej 8\% wagowych), podczas gdy stosunek tlenku aluminium do tlenku krzemu jest zbliżony do innych glin.

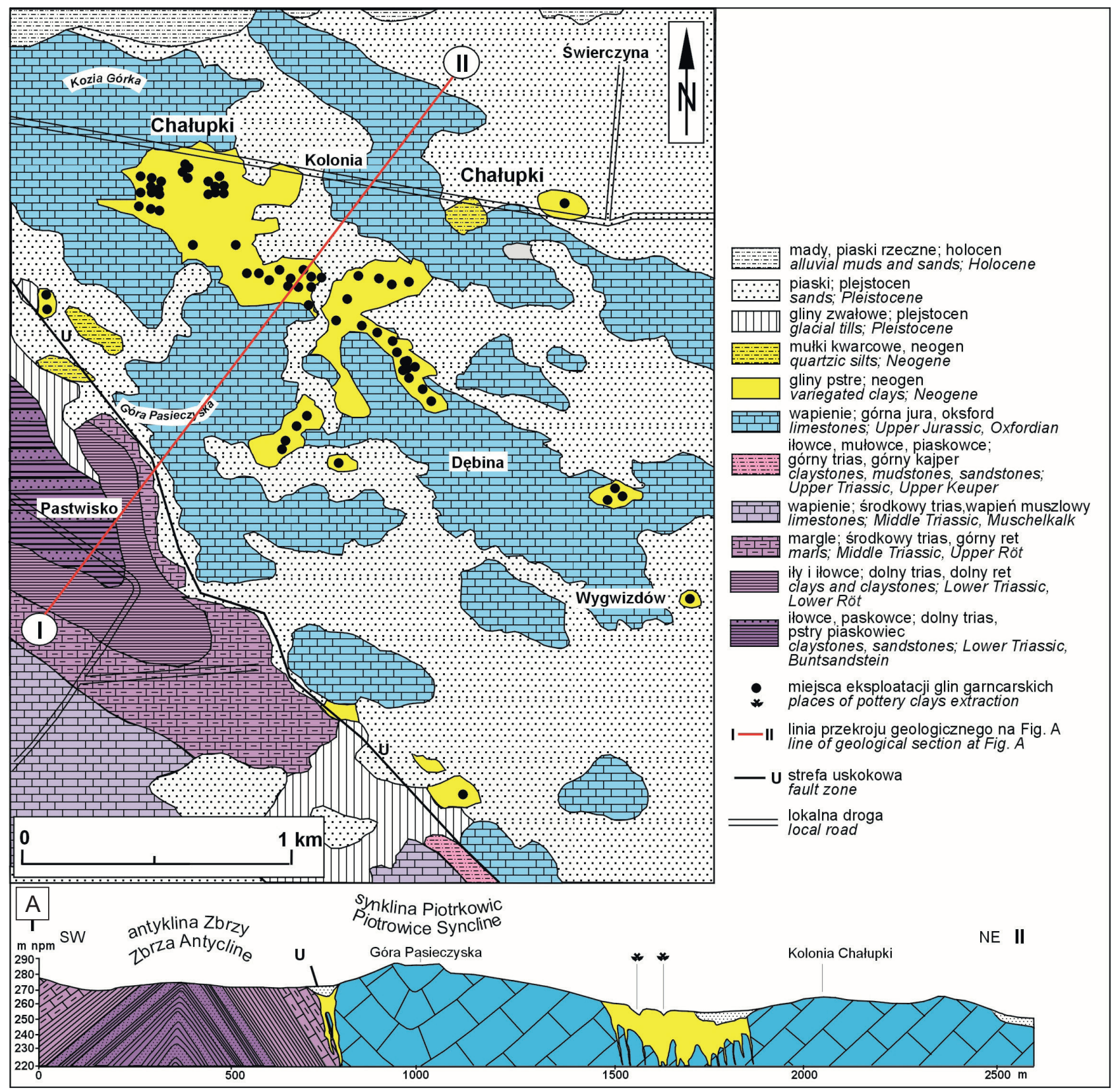

Fig. 3. Mapa geologiczna odkryta rejonu Chałupek (wg Filonowicza, 1967; Fijałkowska \& Fijałkowski, 1984) i przekrój geologiczny (A) (wg Fijałkowska \& Fijałkowski, 1984) - Uncovered geological map of the Chałupki area (according to Filonowicz, 1967; Fijałkowska \& Fijałkowski, 1984) and geological section (A) (according to Fijałkowska \& Fijałkowski, 1984) 


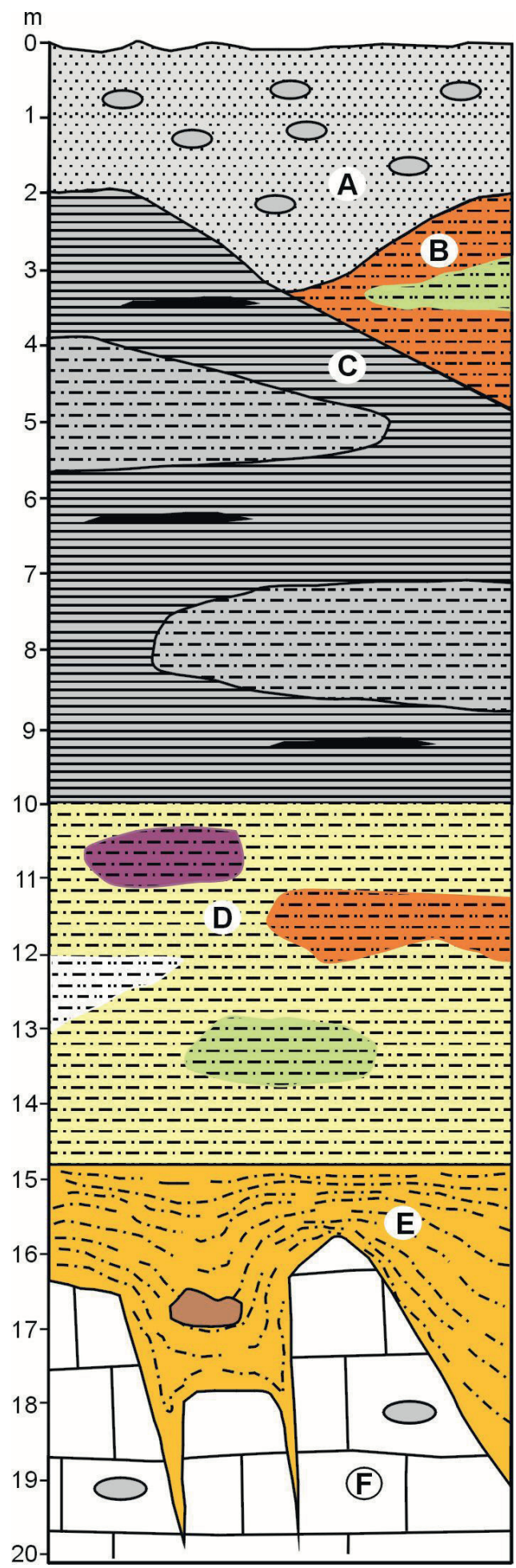

Glinę pozyskiwano, kopiąc płytkie doły (Fig. 5) lub głębsze (do $10 \mathrm{~m}$ ) szybiki, z których urobek wydobywano za pomocą kołowrotów (Fig. 6). Po wyczerpaniu się lokalnych złóż, od 1974 r. glinę dowożono z okolic położonego $30 \mathrm{~km}$ na wschód Łagowa, a od lat 80. - z rejonu Strzegomia na Przedgórzu Sudeckim.

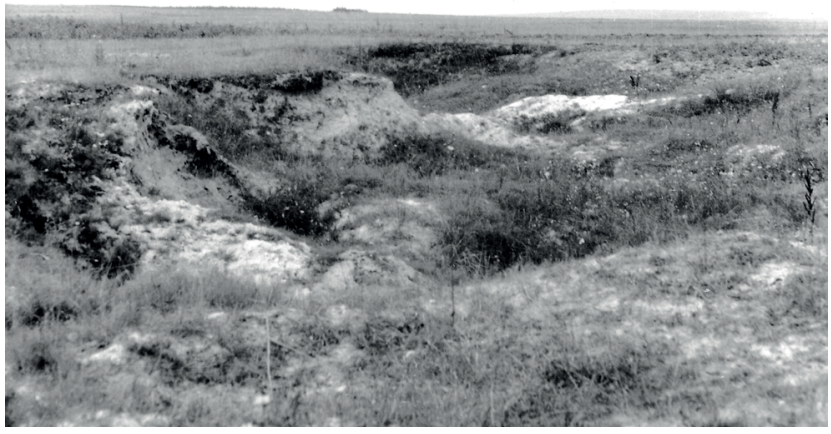

Fig. 5. Szybiki garncarskie koło Góry Pasiecznej, Chałupki, stan z roku 1984, fot. J. Fijałkowski (Zbiory Muzeum Narodowego w Kielcach (MNKi), MNKi/Pf/1907) • Pottery pits near the Pasieczna Hill, Chałupki, status from 1984, photo J. Fijałkowski (Collection of the National Muzeum in Kielce (MNKi), MNKi/ $\mathrm{Pf} / 1907)$

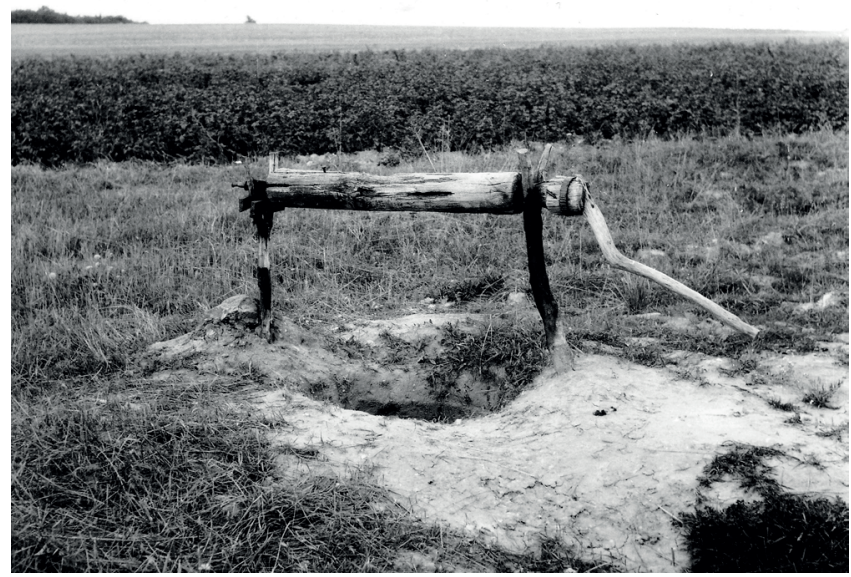

Fig. 6. Szybik garncarski z kołowrotem, okolice Góry Pasiecznej, Chałupki, stan z roku 1984, fot. J. Fijałkowski (MNKi/Pf/1903) - Pottery pit with a turnstile near the Pasieczna Hill, Chałupki, status from 1984, photo J. Fijałkowski (MNKi/Pf/1903)

Fig. 4. Syntetyczny profil osadów neogenu w Chałupkach (wg Fijałkowska \& Fijałkowski, 1984). Objaśnienia: A - pliocen?, B-E - miocen, F - górna jura, oksford; A - piaski kwarcowe szare z krzemieniami górnojurajskimi pochodzącymi z lokalnego podłoża; B - mułki kwarcowe na ogół ceglastej barwy; C - gliny i iły mułkowe szare, poziomo warstwowane, lokalnie z lignitem, górna część kompleksu glin pstrych; D - gliny żółte z gniazdami glin o różnych barwach: wiśniowych, fioletowych, seledynowych, ceglastych i białych z soczewkami mułków kwarcowych białawych i ceglastych, środkowa część kompleksu glin pstrych; E - gliny ochrowe z gniazdami limonitu, dolna część kompleksu glin pstrych; F - skrasowiałe, gruboławicowe wapienie z krzemieniami pasiastymi. • Synthetic profile of Cenozoic deposits at Chałupki (according to Fijałkowska \& Fijałkowski, 1984). Explanations: A - Pliocene?, B-E - Miocene, F - Upper Jurassic, Oxfordian; A - grey quartzic sands, with Upper Jurassic flints derived from the local basement; B - quartzic silts generally reddish-brown; C - grey, horizontal laminated clays and muddy silts, locally with lignite, upper part of the variegated clays' complex; D - yellow clays with nests of multicolour clays: cherry, violet, willow-green, reddish-brown and white and lenses of reddish-brown and white quartzic silts, middle part of the variegated clays' complex; E - ochreous clays with limonite nests, lower part of the variegated clays' complex; F - karstified, thick-bedded limestones with striped flints. 


\section{Produkcja ceramiki}

Prowadzenie warsztatu garncarskiego było przedsięwzięciem rodzinnym i wyjątkowo pracochłonnym. W ciągu roku należało zgromadzić duży zapas gliny, około 15 wozów, które miały wystarczyć na 5-7 wypałów (1,5-2 t na jeden wypał). Wykopywano ją głównie jesienią, zwracając uwagę na czystość, aby nie znajdowały się w niej korzenie roślin, okruchy skał - w szczególności ziarenek marglu, które po wypaleniu powodowały łuskowate odpryski na naczyniach (Skiba, 2000). Glina składowana była blisko warsztatu w zagłębieniu wykopanym w ziemi lub w kojcu z desek. Wymagała jednak wielu zabiegów, które nazywano „gnojeniem” gliny (Fig. 7). Polewano ją wodą i wielokrotnie siekano łopatą, dzięki czemu różne gatunki przywiezionego surowca zostały przemieszane. Przez zimę, poddana warunkom atmosferycznym, macerowała się - bryłki mułu ulegały rozdrobnieniu, a cząstki organiczne - przegniciu. Sezonowanie, które powinno optymalnie trwać dwa lata, zmieniało jej strukturę, dzięki czemu stawała się ona bardziej plastyczna. Po tym procesie glinę zanoszono do warsztatu, gdzie była ubijana drewnianą pałką i cienko strugana nożem wykonanym z blachy lub drutu (Fig. 8). Czynność tę powtarzano trzykrotnie, co miało na celu dokładne wymieszanie materiału i usunięcie wszelkich zanieczyszczeń, m.in. szczątków roślin czy kamyków. Następnie ugniatano ręcznie glinę w celu jej uelastycznienia i usunięcia pęcherzyków powietrza. Tak przygotowany surowiec był kształtowany w gruby słup i stawiany niedaleko toczka. Z niego garncarz odrywał lub odcinał grudy, formował wałek i dzielił go na kłusy odpowiadające wielkości naczyń (Erber, 1984).

Do toczenia naczyń stosowano koło dwutarczowe o ruchomej osi, zwane krągiem lub toczkiem, które przez lata przeszło kilka faz udoskonaleń. Na początku lat 70. ubiegłego wieku zaczęto używać kół o napędzie elektrycznym. Przebieg toczenia był wieloetapowy. Naczynie na koniec pokrywano cienką warstwą rzadkiej gliny w celu uzyskania równej powierzchni. Gotowy wyrób garncarz odcinał od toczka cienkim drutem i ustawiał na desce, tę zaś po zapełnieniu przenosił na podwórze $\mathrm{w}$ miejsce przewiewne w celu wysuszenia (Fig. 9).

Od około 1910 r. zaczęto w Chałupkach wprowadzać płynną glazurę ołowiową, którą przed wypałem polewano naczynia. Wcześniej stosowano ją w postaci suchej, posypując przez specjalne sitko wyroby oblane rozwodnionym roztworem gliny lub rzadkim krochmalem z pszennej mąki.

Glazurę ołowiową z metalicznego ołowiu garncarze przyrządzali sami. Był to proces bardzo uciążliwy i czasochłonny, związany z prażeniem i mieleniem materiału. Roztopiony ołów w czasie prażenia przechodził w postać miałkiego proszku, który, po przesianiu, łączono z pozostałymi składnikami szkliwa, czyli z glinką schudzającą, tzw. piecówką (aby nie sklejała naczyń w czasie wypału), oraz barwnikiem. Jako żółty, czerwony i brunatny barwnik stosowano zmielone rudy żelaza (limonity, hematyty) znajdowane na polach lub w pokładach gliny, przepalone i sproszkowane żużle podymarkowe, również pochodzące z okolicznych pól, lub opiłki żelaza oraz zendrę z kuźni. Barwę zieloną uzyskiwano z przeprażonych i sproszkowanych zwojów drutu miedzianego lub mosiężnego. Kupowano też braunsztyn (dwutlenek manganu), dający zabarwienie brunatno-wiśniowe.

Wypalanie wyrobów prowadzono w piecach garncarskich o pionowym ciągu ognia, zaopatrzonych w poziomą kratę oddzielającą palenisko od komory na naczynia. Jako opał stosowano drewno sosnowe lub osikowe, dające mocny i długi płomień. Wypalanie trwało od sześciu do dziesięciu godzin i zużywano około $2-3 \mathrm{~m}^{3}$ drewna.

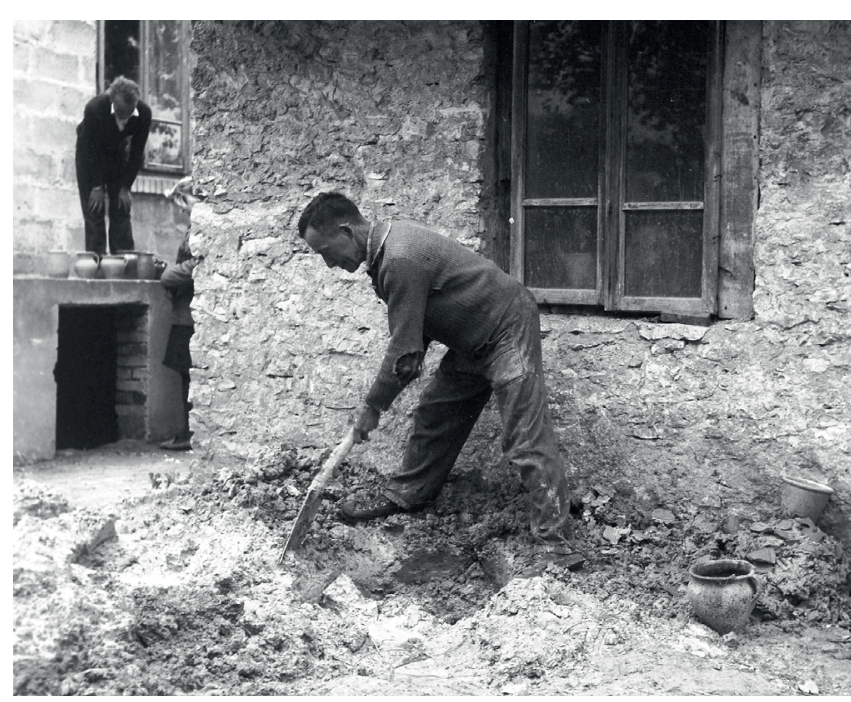

Fig. 7. Garncarz Stefan Sowiński przygotowuje glinę do produkcji (tzw. gnojenie gliny), Chałupki, 1969 r., fot. J. Fijałkowski (MNKi/ $\mathrm{Pf} / 1926)$ - Poterer Stefan Sowiński is preparing clay for ceramic production (clay maceration), Chałupki 1969, photo J. Fijałkowski (MNKi/Pf/1926)

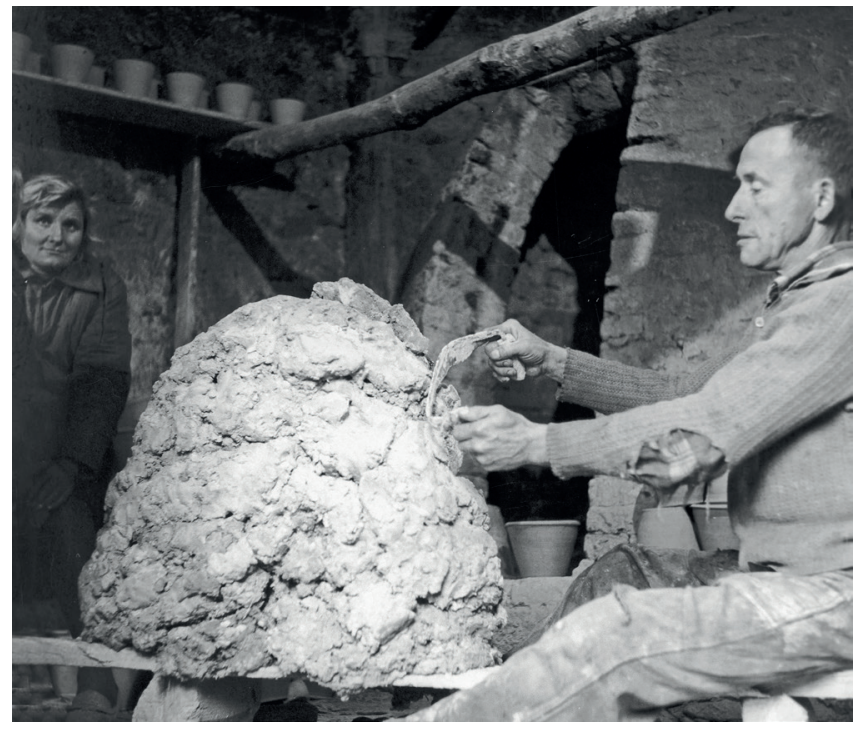

Fig. 8. Struganie gliny, warsztat Stefana Sowińskiego, Chałupki, 1969 r., fot. J. Fijałkowski (MNKi/Pf/1927) • Clay planing, Stefan Sowiński's workshop, Chałupki, 1969, photo J. Fijałkowski (MNKi/Pf/1927) 


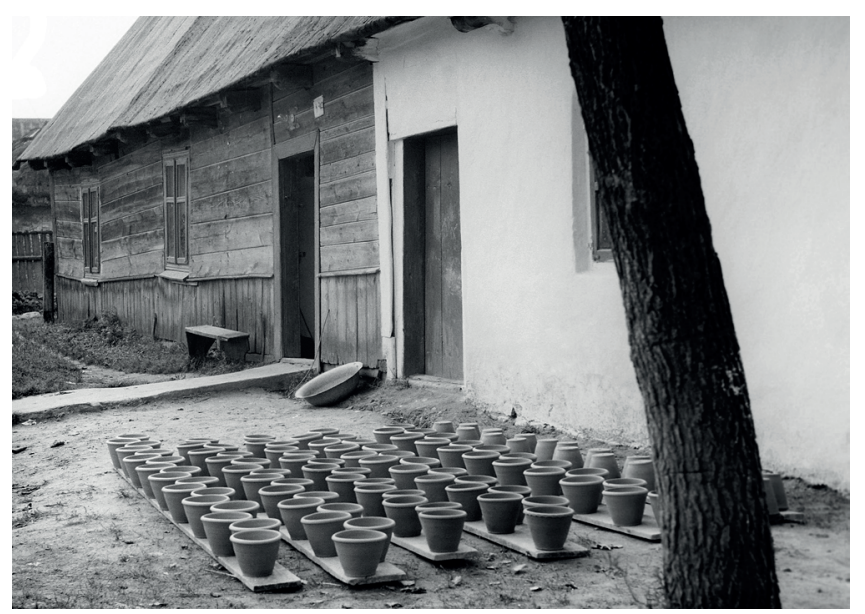

Fig. 9. Suszenie doniczek, Chałupki, 1969 r., fot. J. Fijałkowski (MNKi/Pf/1883) • Drying of flower-pots, Chałupki, 1969, photo J. Fijałkowski (MNKi/Pf/1883)

Naczynia glazurowane na sucho wewnątrz i z zewnątrz wypalano tylko jeden raz, ale starano się je toczyć z mocniejszej (bardziej ilastej) gliny. Przy użyciu płynnej glazury naczynia szkliwione wewnątrz i zewnątrz wypalano dwukrotnie - oblewano je glazurą po pierwszym wypale. Natomiast wyroby szkliwione tylko z zewnątrz wypalano jednorazowo (Erber, 1984; Fig. 10).

\section{Powstanie i funkcjonowanie Ośrodka Tradycji Garncarstwa}

Dzięki zachowaniu się wyposażenia warsztatów garncarskich oraz przeprowadzonym na przełomie lat 60. i 70 . ubiegłego wieku szczegółowym badaniom geologicznym (Fijałkowska \& Fijałkowski, 1984) i etnograficznym (Erber, 1984) w rejonie Chałupek możliwe było utworzenie Ośrodka Tradycji Garncarstwa prowadzącego szerokie spektrum działalności - wystawienniczej, edukacyjnej i folklorystycznej. Dzięki współpracy wielu osób (mieszkańców Chałupek, wojewody kieleckiego) oraz instytucji (samorządu Gminy Morawica, Fundacji im. Stefana Batorego, Muzeum Narodowego w Kielcach, Muzeum Wsi Kieleckiej, Wojewódzkiego Domu Kultury) 4 października 1998 r. otwarto Ośrodek Tradycji Garncarstwa (Fig. 11). Zarządza nim Urząd Miasta i Gminy Morawica oraz Samorządowe Centrum Kultury w Morawicy. Kustoszem muzeum jest Józef Głuszek, syn sławnego i cenionego garncarza z Chałupek Józefa Głuszka, który ma dar przekazywania wiedzy na temat technologii oraz historii garncarstwa w Chałupkach (Erber, 2003; Jastrzębski \& Szczęsny, 2012).

Ośrodek jest unikatowym w skali Polski obiektem, który gromadzi, zabezpiecza i promuje lokalne dziedzictwo garncarstwa Chałupek. Składa się z dwóch części: muzealnej (ekspozycyjnej) oraz edukacyjnej (warsztatowej). W części

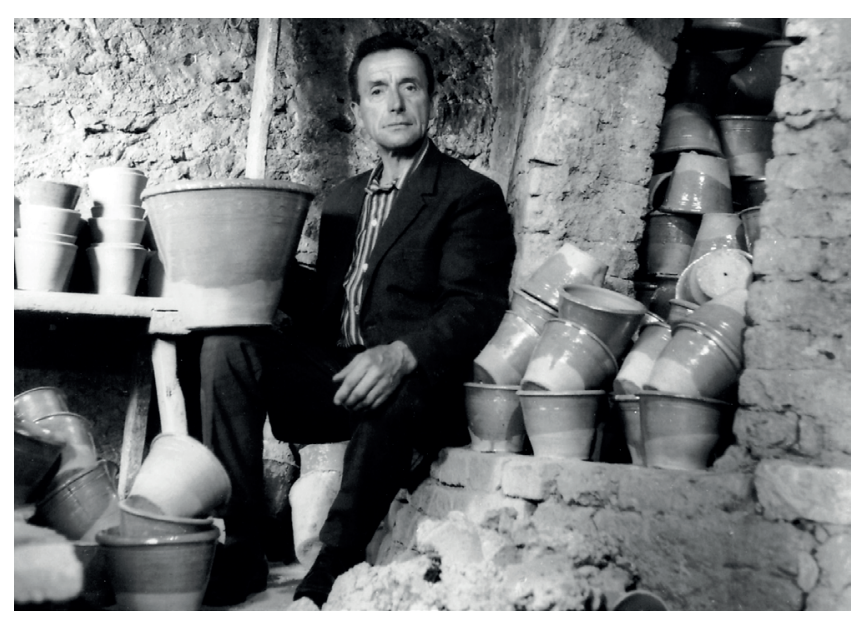

Fig. 10. Stefan Sowiński przy piecu garncarskim, Chałupki, 1969 r., fot. J. Fijałkowski (MNKi/Pf/1900) - Stefan Sowiński by the pottery kiln, Chałupki, 1969, photo J. Fijałkowski (MNKi/Pf/1900)

wystawowej zostały zgromadzone wyroby użytkowe oraz rzeźby ceramiki figuralnej artystów i garncarzy z Chałupek i innych obszarów Polski (Fig. 12). Na szczególną uwagę zasługują rzeźby figuralne, sceny z życia świętych, kropielniczki, kompozycje wielofigurowe, zabawki oraz sceny z życia wsi. Cennym zabytkiem jest oryginalny, dwukomorowy piec garncarski służący do wypalania naczyń (Fig. 13), który znajduje się w swoim pierwotnym miejscu, a pawilon muzealny został wybudowany wokół niego. Obok pieca znajduje się stanowisko pracy z urządzeniami i narzędziami służącymi garncarzowi - dwoma toczkami i nożem do gliny wiszącym na ścianie. Dodatkowo, na pierwszym planie widoczny jest słup gliny (Fig. 13). Dopełnieniem części ekspozycyjnej są tablice objaśniające budowę geologiczną Chałupek w kontekście wydobywania surowca ze złoża oraz historyczne zdjęcia dotyczące technologii produkcji, a także garncarzy przy pracy w swoich warsztatach.

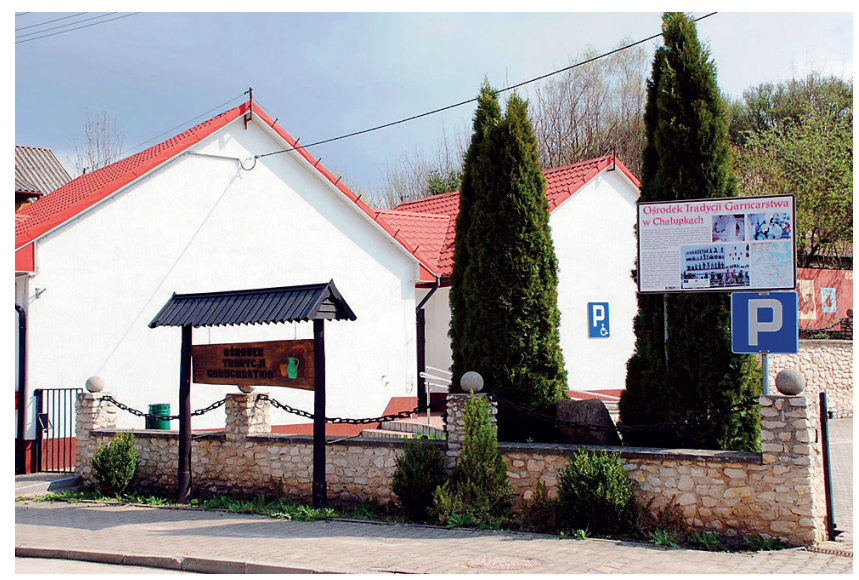

Fig. 11. Ośrodek Tradycji Garncarstwa w Chałupkach, widok ogólny, 2016, fot. G. Pabian - General view of the Pottery Tradition Centre at Chałupki, 2016, photo G. Pabian 


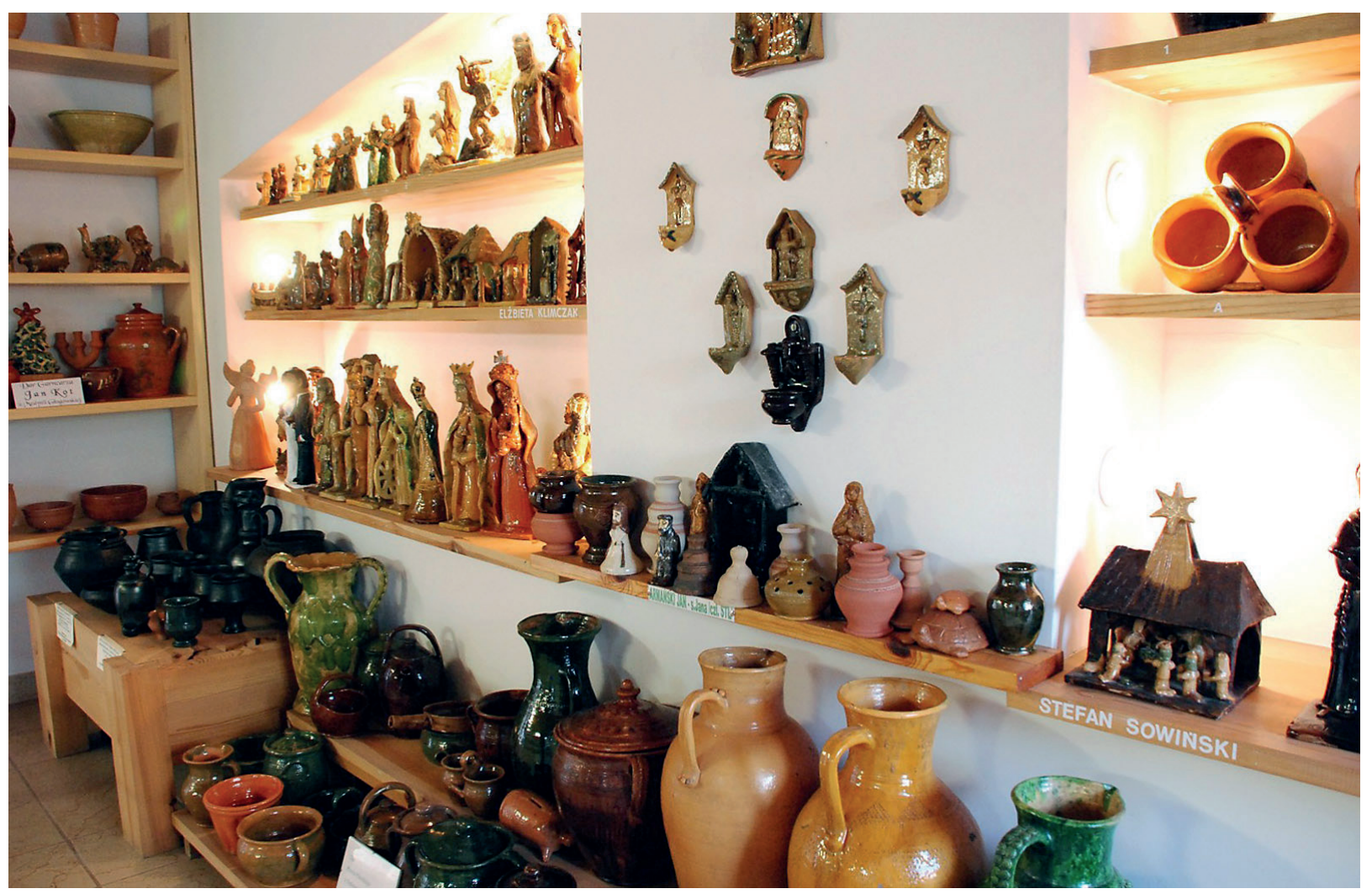

Fig. 12. Część wystawowa ośrodka z eksponatami, 2016, fot. G. Pabian • Museum-exposition part of the Centre, 2016, photo G. Pabian

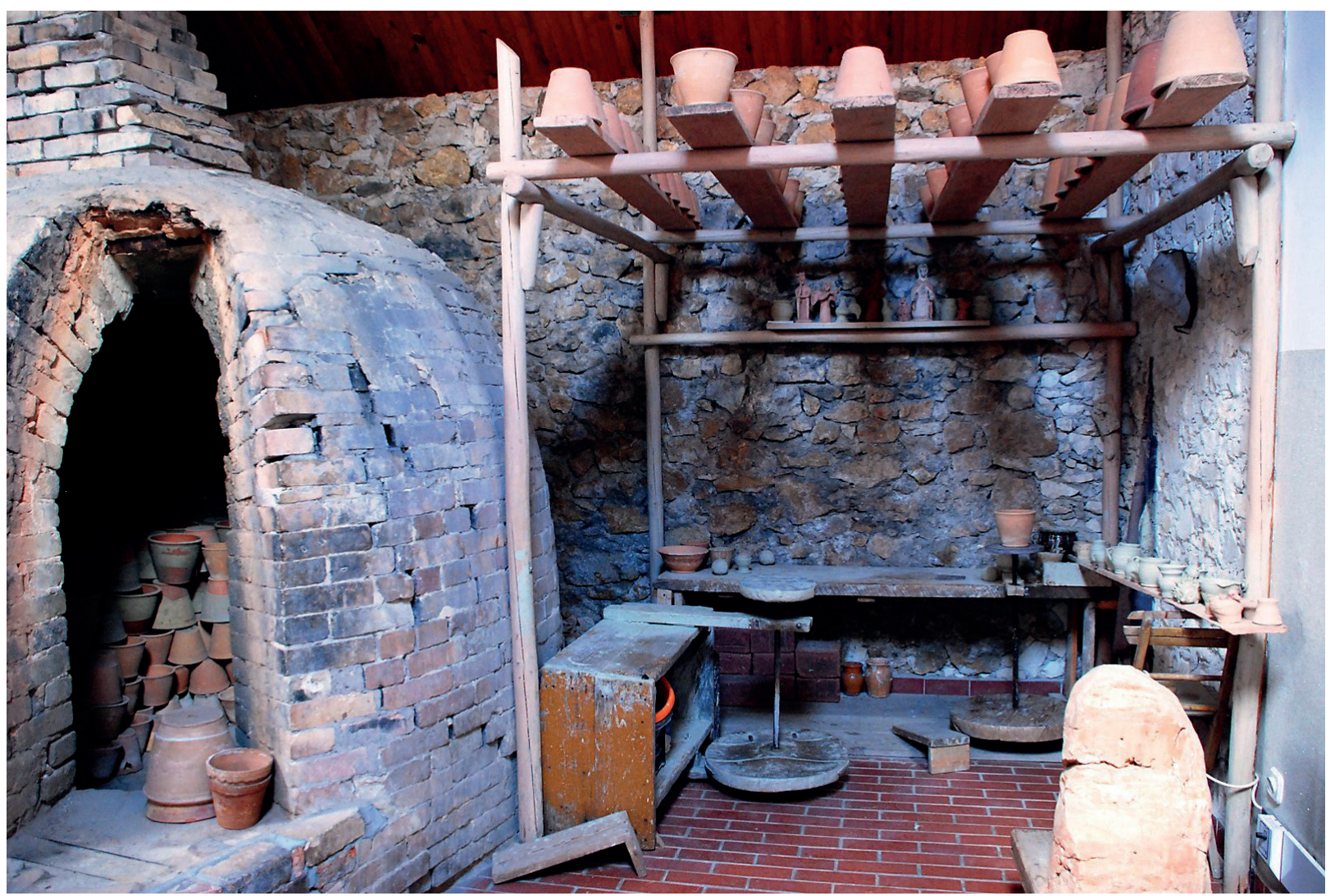

Fig. 13. Zabytkowy, kopułowato sklepiony piec garncarski po lewej stronie i stanowisko pracy garncarza z dwoma toczkami po prawej, 2016, fot. G. Pabian - Original, pottery kiln with a semispherical top at the left side; potter's site, with two wheels at the right side, 2016, photo G. Pabian 


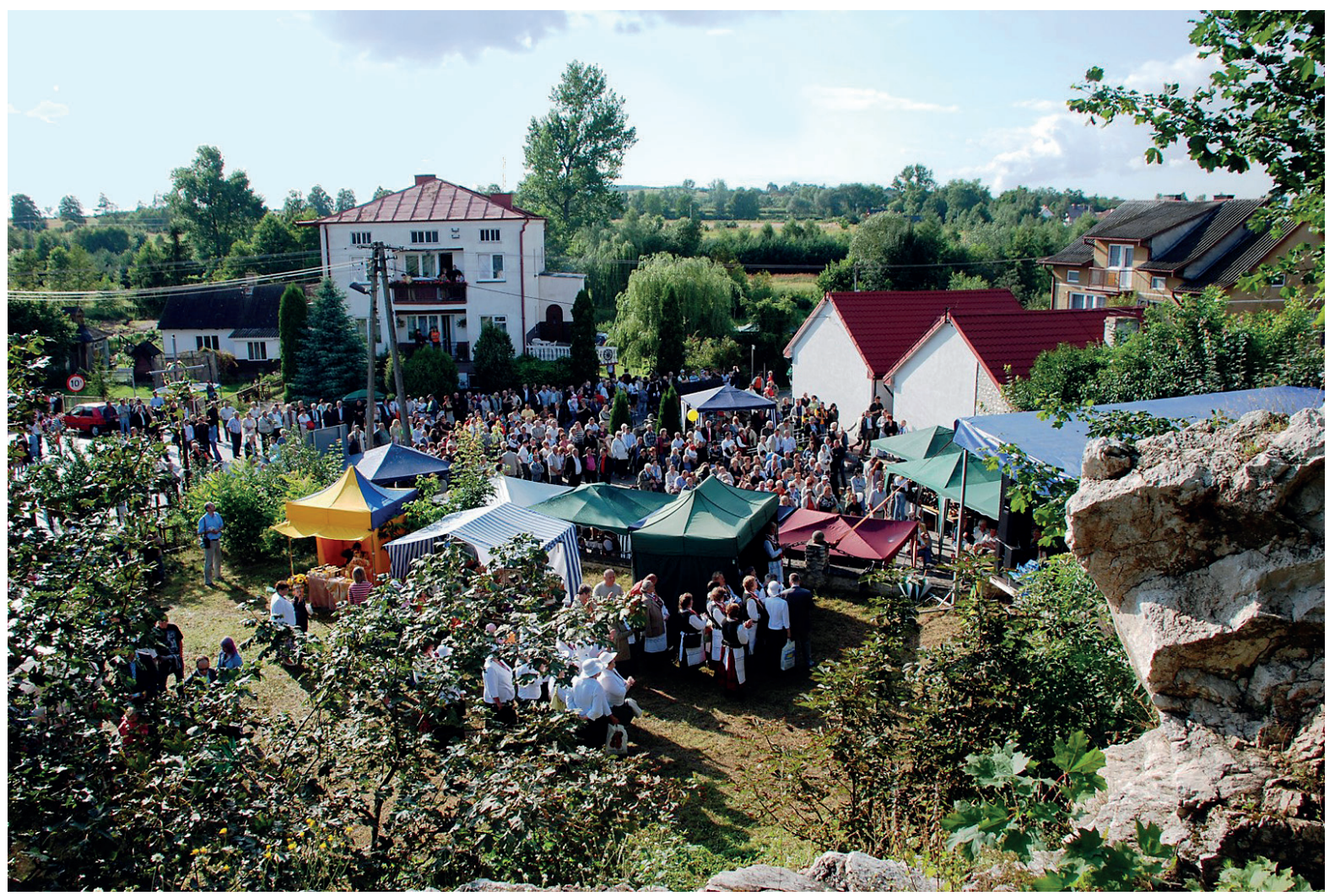

Fig. 14. Festyn etnograficzny „Chałupkowe Garcynki” w Ośrodku Tradycji Garncarstwa, 2009, fot. G. Pabian • „Chałupkowe Garcynki” ethnographic feast in the Pottery Tradition Centre, 2009, photo G. Pabian

Za terenem Ośrodka, po południowo-wschodniej stronie, znajduje się częściowo zrekultywowany kamieniołom stokowy wapienia górnojurajskiego, z którego pozyskiwano surowiec do wypału wapna.

Działalność edukacyjno-warsztatowa realizowana jest z wykorzystaniem zasobów muzeum i przebiega dwuetapowo. Na początku kustosz oprowadza po ośrodku, a zwiedzający dowiadują się o bogatym dziedzictwie kulturowym Chałupek. Następnie znana i ceniona garncarka i rzeźbiarka Elżbieta Klimczak, córka wybitnego garncarza z Chałupek Stefana Sowińskiego, prowadzi warsztaty garncarskie i uczy adeptów garncarstwa tej trudnej sztuki.

Drugim elementem produktu geoturystycznego Chałupek jest coroczne wydarzenie kulturalno-etnograficzne „Chałupkowe Garcynki” (Fig. 14), podczas którego garncarze z Chałupek, regionu świętokrzyskiego oraz innych obszarów Polski prezentują swoje wyroby (Fig. 15). Organizowany jest pokaz toczenia na kole garncarskim połączony z nauką toczenia, któremu towarzyszą konkursy o tematyce związanej z garncarstwem. Punkt kulminacyjny imprezy stanowi obrzęd „Chałupkowych Garcynek”, przygotowany przez zespół folklorystyczny „Brzezinianki”.

Aktualnie na terenie ośrodka realizowany jest projekt mający na celu podniesienie atrakcyjności turystycznej obiektu. W ramach projektu zostanie wykonana modernizacja budynku muzeum oraz nowe zagospodarowanie placu obok ośrodka. W trakcie budowy jest scena estradowa z zapleczem socjalnym i pomieszczeniem na warsztaty garncarskie oraz stoiska dla wystawców podczas wydarzeń kulturalnych. Realizacja tego projektu ma związek ze zwiększającym się ruchem turystycznym oraz funkcjonowaniem ośrodka na obszarze Geoparku „Geoland Świętokrzyski”.

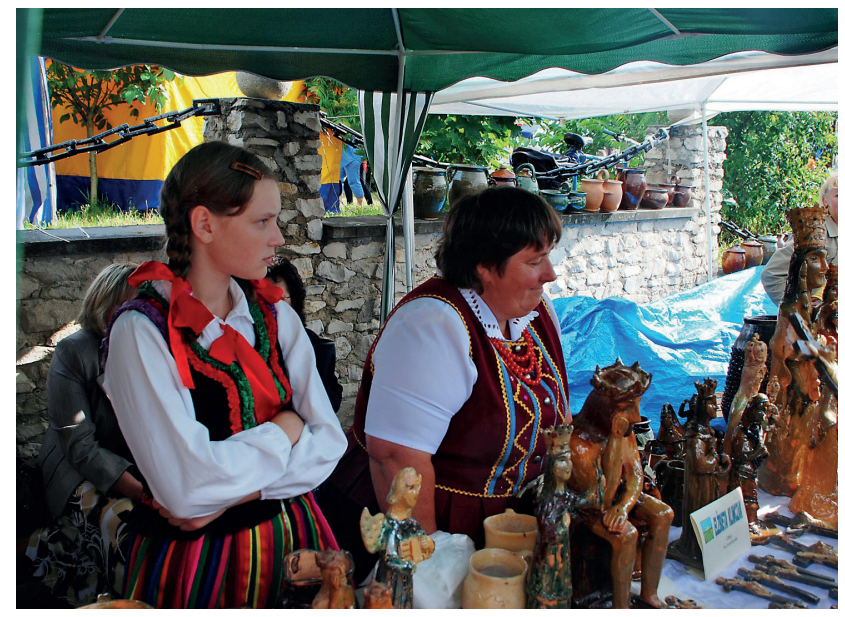

Fig. 15. Stoisko garncarki Elżbiety Klimczak podczas „Chałupkowych Garcynek”, 2009, fot. G. Pabian • Poterer Elżbieta Klimczak's stand during the "Chałupkowe Garcynki”, 2009, photo G. Pabian 


\section{Podsumowanie}

Celem tego artykułu było zwrócenie uwagi na aspekty geoturystyczne Ośrodka Tradycji Garncarstwa w Chałupkach, w którym pokazany jest związek między surowcem mineralnym a wytworzonym z niego produktem. Ośrodek powstał bowiem na bazie wielowiekowej tradycji produkcji ceramiki opartej na lokalnym surowcu - glinach wieku mioceńskiego, wypełniających leje krasowe powstałe w wapieniach górnojurajskich. Ponadto jako barwniki do glazury stosowane były tu rudy żelaza znajdowane na polach lub w pokładach gliny i żużle podymarkowe, także pochodzące z okolicznych pól.
Ekspozycja i organizowane warsztaty przybliżają turyście wieloetapowy proces produkcji ceramiki - od pozyskania gliny i jej uzdatnienia, przez formowanie naczyń, pierwotnie ręczne, później na toczku, szkliwienie i w końcu wypał. Na podkreślenie zasługuje też lokalizacja Ośrodka przy dawnym kamieniołomie wapieni górnojurajskich, z których wypalano wapno na potrzeby lokalne. Dzięki prowadzeniu różnorodnej działalności wystawienniczej, edukacyjnej i folklorystycznej Ośrodek ocala od zapomnienia tradycję i dawne techniki produkcji ceramiki oraz promuje dziedzictwo kulturowe i geologiczne Chałupek.

Autorzy składają podziękowanie Recenzentom za cenne wskazówki i uwagi.

\section{Literatura (References)}

Carosi Ph., 1781/1784. Reisen durch polnische Provinzen: mineralogische und andere Inhalte. T. 1, 2, Leipzig.

Czarnocki J., 1927. Sprawozdanie z badań dokonanych w r. 1926 w związku z ogólnym poglądem na budowę mas mezozoicznych regionu chęcińskiego. Posiedzenia Naukowe Państwowego Instytutu Geologicznego, 17: 1-3.

Drzał M., 1966. Kras kopalny na obszarze między Pilicą a Nidą. $A n-$ nales Universitatis Mariae Curie-Skłodowska, Sec. B, 19: 63-10.

Erber B., 1984. Ośrodek garncarski w Chałupkach. Rocznik Muzeum Narodowego w Kielcach, 13: 293-347.

Erber B., 2003. Garncarstwo w Chałupkach (II połowa XIX, wiek XX). W: Kowalska D. (red.), Morawica szkic do portretu gminy. Towarzystwo Przyjaciół Ziemi Morawickiej, Morawica: 156-179.

Fijałkowska A., 1988. Uwagi o trzeciorzędzie lądowym Gór Świętokrzyskich. Kwartalnik Geologiczny, 32: 513.

Fijałkowska E. \& Fijałkowski J., 1965. Charakterystyka trzeciorzędu lądowego w zachodniej części Gór Świętokrzyskich. Rocznik Muzeum Świętokrzyskiego w Kielcach, 3: 385-410.

Fijałkowska E. \& Fijałkowski J., 1984. Występowanie glin garncarskich w rejonie Chałupek. Rocznik Muzeum Narodowego w Kielcach, 13: 349-376.

Filonowicz P., 1967. Szczegółowa mapa geologiczna Polski 1:50 000. Arkusz Morawica (M34-42C). Wydawnictwa Geologiczne, Warszawa.

Filonowicz P., 1968. Objaśnienia do szczegółowej mapy geologicznej Polski 1:50 000. Arkusz Morawica (M34-42C). Wydawnictwa Geologiczne, Warszawa.

Jastrzębski C. \& Szczęsny G., 2012. Morawica. Przewodnik turystyczny. Oddział Świętokrzyski PTTK w Kielcach, Kielce.

Kondracki J., 2002. Geografia regionalna Polski. Wydawnictwo Naukowe PWN, Warszawa.

Kosmowska-Suffczyńska D., 1966. Rozwój rzeźby w trzeciorzędzie okolic Ostrowca Świętokrzyskiego i Ćmielowa. Polska Akademia Nauk. Instytut Geografii. Prace Geograficzne, 54: 1-114.

Ludwikowska-Kędzia M., 2018. Stanowisko 5. Winna. Kopalnia dolomitów Winna - mioceńskie wypełnienia lejów krasowych. W: Ludwikowska-Kędzia M. \& Wiatrak M. (red.), XXV Konferencja Naukowa Stratygrafia Plejstocenu Polski. Plejstocen Gór Świętokrzyskich. Huta Szklana, 3-7 września 2018 r. Politechnika Świętokrzyska, Uniwersytet Jana Kochanowskiego, Kielce, 201-204.

Majchert H., 1966. Kras kopalny w południowo-zachodniej części Gór Świętokrzyskich. Prace Muzeum Ziemi, 9: 132-145.

Samsonowicz J., 1923. Sprawozdanie z badań geologicznych na północnym zboczu Gór Świętokrzyskich. Posiedzenia Naukowe Państwowego Instytutu Geologicznego, 6: 8-10.

Skiba P., 2000. Garncarstwo. Sztuka pięciu żywiołów. Wydawnictwo „Arkady”, Warszawa.

Stupnicka E., 1972. Tektonika południowo-zachodniego obrzeżenia Gór Świętokrzyskich. Biuletyn Geologiczny Uniwersytetu Warszawskiego, 14: 21-114.

Urban J. (red.), 1996. Jaskinie regionu świętokrzyskiego. Polskie Towarzystwo Przyjaciół Nauk o Ziemi, Warszawa.

Walczowski A., 1966. Zjawiska krasowe południowo-zachodniego obrzeżenia Gór Świętokrzyskich. Annales Universitatis Mariae Curie-Sktodowska, Sec. B, 19: 29-52.

Wróblewscy T. i E., 1996. Góry Świętokrzyskie. Mapa geologicznokrajoznawcza 1:200 000. Wydawnictwo Kartograficzne Polskiej Agencji Ekologicznej, Warszawa.

Złonkiewicz Z. \& Kasza A., 2016. Kras w obrzeżeniu permsko-mezozoicznym Gór Świętokrzyskich. W: Urban J. (red.), Materiaty 50. Sympozjum Speleologicznego, Kielce-Chęciny, 2-23.10.2016: 169-174.

Niniejszy artykuł stanowi rozszerzenie referatu wygłoszonego w ramach IV Forum GEO-PRODUKT, które odbyło się w dniach 27-28 września 2018 roku w Ośrodku Edukacji Ekologiczno-Geologicznej GEOsfera w Jaworznie.

This paper is extended versions of presentations delivered during the IV Forum GEO-PRODUKT, which was held on September, 27-28, 2018 in Jaworzno, Poland (Ecological and Geological Education Center GEOsfera). 